\title{
Revision of the morphology and biogeography of Thysanorea papuana
}

\author{
Kirschner $\mathbf{R}^{1}$ \\ ${ }^{1}$ Department of Life Sciences, National Central University, 320 Taoyuan City, Zhongli District, Taiwan, \\ kirschner@ncu.edu.tw
}

Kirschner R 2016 - Revision of the morphology and biogeography of Thysanorea papuana. Mycosphere 7(6), 820-827, Doi 10.5943/mycosphere/7/6/13

\begin{abstract}
The monotypic genus Thysanorea (Chaetothyriomycetes) is characterized by Periconiellalike penicillate conidiophores. The morphology and geographic distribution of Thysanorea papuana are revised based on fresh collections from Taiwan, literature research, and type studies. It is revealed that the original morphological generic characterization is based on cultivation artifacts. On the natural substrate and in fresh isolates, conidiophore heads appear less complex and are shed off and replaced by repeated percurrent regeneration. The species was previously known from Papua New Guinea and India, while this is the first record from Taiwan. Ramichloridium lignicola, which was recorded from Hong Kong and Thailand is recognized as synonymous and Alysidiopsis lignicola recorded from Mexico is a possible synonym. The distribution of this species appears to be paleotropical or even pantropical.
\end{abstract}

Key words - dematiaceous hyphomycetes - ITS sequences - new record

\section{Introduction}

The genus Thysanorea with the single species, Th. papuana based on Periconiella papuana Aptroot, was proposed because of its phylogenetic placement among Rhinocladiella species in the Chaetothyriomycetes, whereas all other Periconiella species nest within a clade of Mycosphaerellaceae of Dothideomycetes, including species of Ramichloridium and Zasmidium (Arzanlou et al. 2007). As the species name indicates, the fungus was first discovered in Papua New Guinea, but was recently also found in India (Pratibha \& Prabhugaonkar 2015). Since many dematiaceous hyphomycetes on leaf and branch litter show a distinct species-specific morphology, sufficient for species identification, many new species and records are presently being described based on morphology alone (Moro et al. 2015, Kodsueb et al. 2016, Ma et al. 2016a, b, MenaPortales et al. 2016, Silva et al. 2016, Xia et al. 2016), although a high proportion could be cultivated and subjected to molecular analysis (Pratibha \& Prabhugaonkar 2015, Hashimoto et al. 2016, Heidarian et al. 2016, Pratibha et al. 2016). DNA sequence data are helpful particularly when the generic delimitations are quite artificial, so that the same species is likely to be described independently by different researchers in different genera. Research of new collections of Thysanorea specimens in Taiwan and in recent literature, also indicated a widespread distribution, not only geographically, but also taxonomically, in different genera. Detailed comparison of the conidiophore morphologies in nature and in culture revealed a feature which might be useful for morphological characterization of the genus. 


\section{Materials \& Methods}

\section{Isolates and morphology}

Two specimens were collected on dead woody substrates in northern and southern Taiwan, respectively, and deposited in the Museum of Natural Science, Taichung, Taiwan (TNM). Isolation of pure culture and morphological investigation were conducted as described in Kirschner (2016). Air-dried specimens from field collections were mounted on stubs, sputter-coated with gold and investigated with scanning electron microscopy (SEM) using a low vacuum scanning electron microscope at National Central University. Loans of type specimens were requested from the herbaria of the Centraalbureau voor Schimmelcultures, Utrecht, The Netherlands (CBS-H), Instituto de Ecología y Sistemática, Havana, Cuba (HAC), and the International Fungal Research \& Development Centre, Kunming, China (IFRD). A number of Facesoffungi is included as explained in Jayasiri et al. (2015).

\section{DNA techniques}

Nuclear DNA extraction from a living culture (BCRC FU30287), PCR amplification of the internal transcribed spacer region (ITS) of the ribosomal RNA gene, sequencing and editing were performed as in Yeh \& Kirschner (2014). The obtained sequence was deposited in GenBank (KX894451) and subjected to BLAST search.

\section{Results}

The original descriptions and illustrations of Alysidiopsis lignicola and Ramichloridium lignicola are almost identical to those of the specimens collected in Taiwan and identified with $T h$. papuana. Since the type of A. lignicola could not be traced in HAC (J. Mena, pers. comm.) and no conidiophore heads could be found in the type of $R$. lignicola, comparison between these species and Th. papuana was based only on the original publications. Light microscopic observations were shown in Figs 1-13. SEM photographs from the holotype of Thysanorea papuana (CBS-H) and specimen R. Kirschner \& C.-J. Chen 1356 from Taiwan showed that conidia and conidiogenous cells were smooth and conidiogenous loci were conical and had plane secession scars (Figs 14-16).

BLAST search at GenBank with a $646 \mathrm{~b}$ long sequence from a Taiwanese cultured specimen (GenBank KX894451) revealed 97\% (562/579 b) identity with the sequence of the ex-type culture of Th. papuana (NR111276) and 98\% (587/596 b) identity with that of a strain from India (KR259881). The next similar sequences were from species of Minimelanolocus R.F. Castañeda \& Heredia with unbranched conidiophores (Liu et al. 2015) with ITS sequence similarities of 93\%.

\section{Taxonomy}

Thysanorea papuana (Aptroot) Arzanlou, W. Gams \& Crous, Stud. Mycol. 58 : 80 (2007) Figs 1-16

三Periconiella papuana Aptroot, Nova Hedwigia 67(3-4): 491 (1998)

= Ramichloridium lignicola K.M. Tsui, Goh, K.D. Hyde \& Hodgkiss, Cryptog. Mycol. 22(2): 141 (2001), syn. nov.

$?=$ Alysidiopsis lignicola Mercado, Figueras \& J. Mena, Mycotaxon 60: 444 (1996)

Facesoffungi Number: FoF02731

\section{Morphology on the natural substrate:}

Specimens from Taiwan:

Sexual morph: Undetermined. Asexual morph: Hyphomycetous. Conidiophores single, micro- to macronematous, erect, straight, smooth, dark brown, becoming paler towards the apex, macronematous conidiophores 132-458 $\mu \mathrm{m}$ high, composed of unbranched stipe and branched head, stipe often with a percurrent proliferation close below the branched head, 6-14 $\mu \mathrm{m}$ wide at the base, 3-6 $\mu \mathrm{m}$ wide at the apex, head appr. 20-50 $\mu \mathrm{m}$ long and 15-55 $\mu \mathrm{m}$ wide, head and 
branches easily breaking off, branches irregular in number, branching pattern and cellular composition, but always composed of basal sterile cells and conidiogenous cells and often constricted at the septa, smooth-walled, paler than the stipe. Conidiogenous cells intercalary and terminal, basal half often swollen and distinct from apical half bearing several conidiogenous scars and sometimes being bent, (3-)5-10.5(-13) $\times(2-) 3-4(-5) \times(2-) 3-4(-5) \mu \mathrm{m}(\mathrm{n}=30$, R. Kirschner 4019). Conidiogenous loci short-cylindrical, with thickened and darkened wall at the truncate apex, $1 \times 1 \mu \mathrm{m}$. Conidia solitary, clavate or short-cylindrical, sometimes slightly constricted, $0-3$-septate, but 3 -septate conidium $(12 \times 3 \mu \mathrm{m})$ only found once, 2 -septate conidia being rare, aseptate conidia rare in R. Kirschner 4019, pale brown, smooth, (5-)6-8(-9) $\times(1.5-) 2-3 \mu \mathrm{m}(\mathrm{n}=15$, R. Kirschner \& C.-J. Chen 1356) or (6-)7-9(-9.5) × 2.5-3 ( $\mathrm{n}=30$, R. Kirschner 4019), basal hilum conspicuous, thickened and darkened, 1-1.5 $\mu \mathrm{m}$ wide. Micro- and semimacronematous conidiophores inconspicuous, arising from superficial hyphae close to the macronematous conidiophores, branched or unbranched, with conidiogenous cells and conidia basically identical to those from macronematous conidiophores.

Holotype (from Papua New Guinea):

Conidiophores appr. $205 \mu \mathrm{m}$ high, stipe 5-8 $\mu \mathrm{m}$ wide, dark brown, cell wall smooth, 1-1.5 $\mu \mathrm{m}$ thick, with percurrent proliferations below the conidiogenous head, head similar to that described above, with 3 levels of branching, conidiogenous cells terminal and intercalary, of similar shape as described above, pale brown, smooth, 8-12 × 3-4 $\mu \mathrm{m}$, conidiogenous loci blackened, 0.5$1 \times 0.5-1 \mu \mathrm{m}$. Conidia clavate or short-cylindrical, sometimes slightly constricted, 1-3-septate, but 1-septate conidia most frequent, pale brown, smooth, 8-11 $\times 3-3.5 \mu \mathrm{m}$, basal hilum conspicuous, darkened, $1 \times 1 \mu \mathrm{m}$.

\section{Morphology in culture on corn meal agar:}

Colony dark brown, velutinous, hyphae pale brown, smooth, 1-3 $\mu \mathrm{m}$ wide. Conidiophores micronematous to macronematous, micronematous ones pale brown, reduced to a conidiogenous cell or few branches, semimacronematous ones dark brown, appr. 50-70 $\mu \mathrm{m}$ long, macronematous ones 125-230 $\mu \mathrm{m}$ long, with dark brown, smooth stipe, 100-200 $\times 4-10 \mu \mathrm{m}$, without percurrent proliferations, basal cell often subglobose and strongly swollen, up to $15 \mu \mathrm{m}$ wide, conidiophore base sometimes rhizoidal, apex formed of sparse, irregularly clustered branches similar to those on the natural substrate, branches easily breaking off from the stipe, of the same color as the stipe or paler, paler towards the apex, smooth, mostly 2-4-celled, 3-5 $\mu \mathrm{m}$ wide at the swollen basal base that becomes delimited from the conidiogenous cell by the formation of a septum. Mature conidiogenous cells intercalary and terminal on the branches, cylindrical, geniculate, pale brown, smooth, terminal ones $(6-) 7-10(-11) \times 2-3 \mu \mathrm{m}(\mathrm{n}=30)$, covered by numerous blackened conidiogenous loci, $0.5-1 \times 0.5-1 \mu \mathrm{m}$. Conidia solitary, clavate or short-cylindrical, sometimes slightly curved towards the base, 0 -2-septate, but 1-septate conidia most frequent, pale brown, smooth, $(6-) 7-10(-11) \times 2-3 \mu \mathrm{m}(\mathrm{n}=30)$, basal hilum conspicuous, darkened, $1 \times 1 \mu \mathrm{m}$.

Known habitats and distribution - on terrestrial and submerged branches, Hong Kong (Tsui et al. 2001), India (Pratibha \& Prabhugaonkar 2015), ?Mexico (Mercado et al. 1996), Papua New Guinea (Aptroot \& van Iperen 1998), Taiwan (new record), Thailand (Kodsueb et al. 2016).

Material examined - Hong Kong, Tai Po, Lam Tsuen River, on dead submerged branch, April 1997, K.M. Tsui KM 171 [formerly HKU(M), now IFRD, holotype of Ramichloridium lignicola, in poor condition, without conidiogenous heads and conidia], Papua New Guinea, Madang Province, foothill of Finisterre range, $40.8 \mathrm{~km}$ along road Madang-Lae, alt. $200 \mathrm{~m}$, on stipe of unknown plant, 2 November 1995, A. Aptroot 36647 (CBS-H 6351, holotype of Thysanorea papuana), Taiwan, Kaohsiung County, between Baolai and Jiaxian, 400-600 m, on branch on ground, 6 July 2002, R. Kirschner \& C.-J. Chen 1356 (TNM), Taoyuan City, Shihmen Dam area, 
ca. 250 m, on rotting wood on ground, 16 April 2014, R. Kirschner 4019 (TNM), - living culture: BCRC FU30287, - ITS sequence: GenBank KX894451.

\section{Discussion}

\section{Conspecificity}

The morphological similarity between Alysidiopsis lignicola, Ramichloridium lignicola, and Thysanorea papuana indicates conspecificity. The presence of short conidial chains in addition to solitary conidia mentioned for A. lignicola was indicated as the single difference to $R$. lignicola by Tsui et al. (2001). Catenate conidia cannot be deduced from the illustration of A. lignicola showing only solitary conidia with a basal hilum without a further scar at the apex (Mercado et al. 1996). Because no material of A. lignicola was available, a new synonymy with and combination into Thysanorea is not yet proposed. Conidia from field collections were 0-2-septate in the specimens from Taiwan and Hong Kong (Tsui et al. 2001), whereas 3-septate conidia were found in the field collection from Papua New Guinea (up to 2-septate in Aptroot \& van Iperen 1998) and a single 3 septate conidium in a Taiwanese specimen, but only 0-1-septate ones in culture of Th. papuana (Arzanlou et al. 2007) and in the field collection of A. lignicola (Mercado et al. 1996) as well as in the specimen from India (Pratibha \& Prabhugaonkar 2015). The number of septa found in the conidia, therefore, depends from environmental factors and the investigator, but in all cases, 1septate conidia are predominant. Conidiogenous heads and conidia could not be found in the holotype of $R$. lignicola. The photographs of the type and the original description (Tsui et al. 2001), however, agree generally with the morphology of the Taiwanese specimens. Although the conidiophores exceed the length of that described by Tsui et al. (2001), the measurements of the specimen from Taiwan generally fit to the ranges given for the specimen described from Hong Kong (Tsui et al. 2001) and those from India (Pratibha \& Prabhugaonkar 2015). The ITS divergence of $2-3 \%$ between the strains from India, Papua New Guinea and Taiwan is within the generally accepted 3\% threshold for considering different strains as conspecific (Blaalid et al. 2013).

\section{Generic delimitation}

In order to avoid confusion by different morphologies in nature and in culture, both have to be studied and connected to each other in documentation of the same species (Gams 2002). Since this approach was not applied in Thysanorea previously, the species and genus concept has become confused, particularly since the type material has been practically lost in Alysidiopsis lignicola and Ramichloridium lignicola so that the published illustrations serve as reference for taxonomic conclusions. Mercado et al. (1996) felt that Alysidiopsis appeared artificial and suggested detailed comparison with Cladosporium and related genera. The ultrastructure of conidiogenous loci, though emphasized as important for generic delimitations of Cladosporium-like fungi by Arzanlou et al. (2007), was not investigated by the authors. The SEM photographs showing conical conidiogenous loci with smooth secession scar in the holotype of Thysanorea papuana and a specimen from Taiwan (Figs 14-16) were identical to those of Alysidiopsis lignicola (Mercado et al. 1996). This ultrastruture is hardly distinguishable from that of Periconiella species (Kirschner \& Piepenbring 2008, Kirschner \& Chen 2010). The genus and species concept of Th. papuana with a complex conidiogenous head and $0-1$-septate conidia was based only on culture characteristics (Arzanlou et al. 2007). Morphological separation of the genus from Periconiella was not accomplished, but based only on a gradually more (up to six times) branched head and presence of "micronematous" conidiophores in culture of Th. papuana. Less complex conidiophores (i.e. not composed of a long stipe and a branched head), however, also occur in true (phylogenetically supported) Periconiella species, e.g. P. machilicola, as well as complex heads with up to four levels of branches (Kirschner \& Chen 2010). Ramichloridium-like conidiophores were also recorded for a species tentatively identified as $P$. geonomae (Kirschner et al. 2014). On the natural substrate and in fresh culture, conidiogenous heads of Th. papuana are not as complex as after 

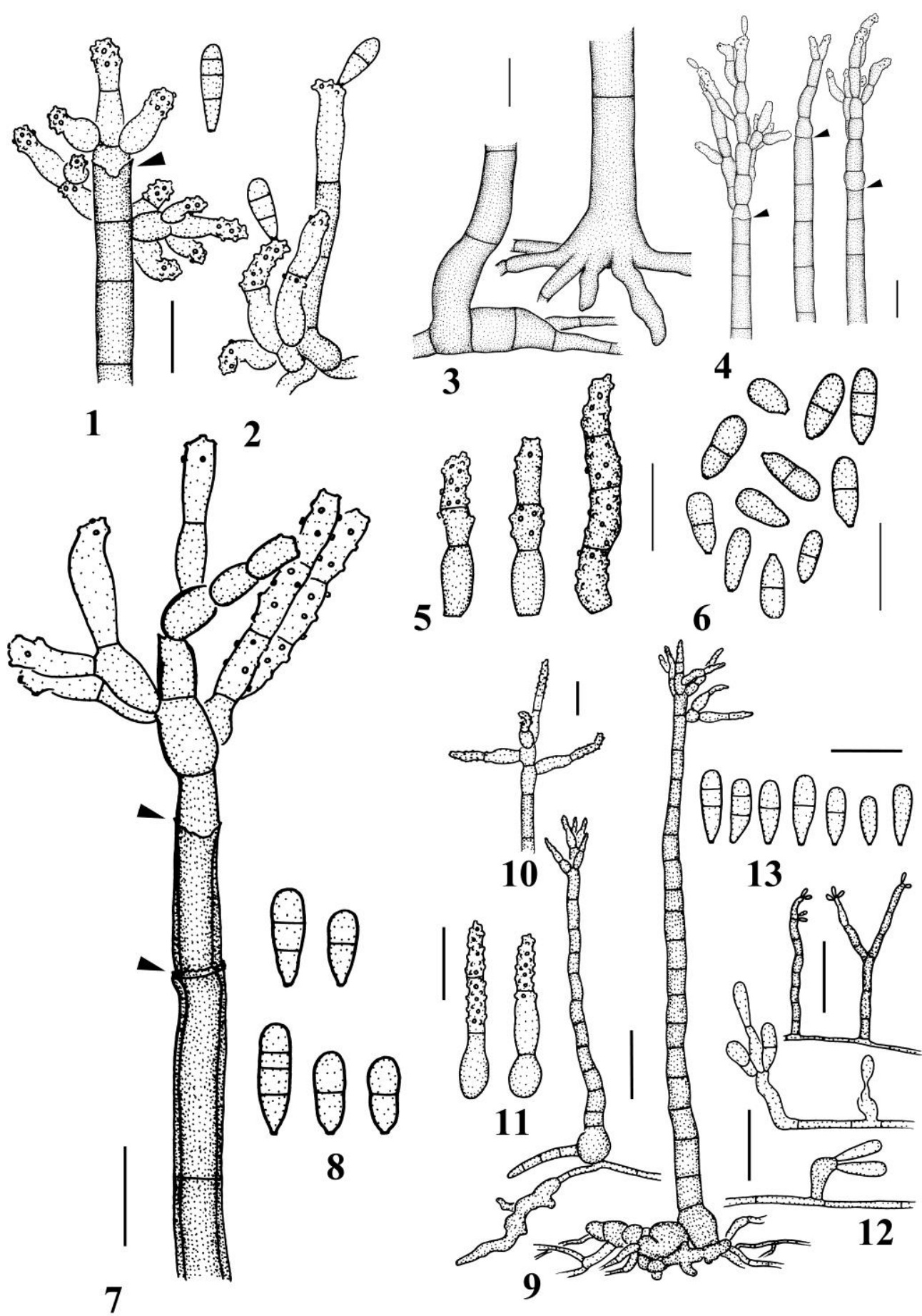

Figs 1-13 - Drawings of Thysanorea papuana. 1-8 Specimens from natural substrate (1, 2 R. Kirschner 4019, Taiwan; 3-6 R. Kirschner \& C.-J. Chen 1356, Taiwan; 7, 8 holotype, Papua New Guinea). 1 Apex of penicillate conidiophore showing a percurrent extension (arrowhead) and a 3septate conidium. 2 Semimacronematous conidiophores not differentiated into stipe and head. 3 Bases of penicillate conidiophores, the right one with aseptate rhizoids, the left one with few several-celled supporting hyphae. 4 Conidiophore apices, note percurrent proliferations of the stipe (arrowheads). 5 Detached conidiophore branches with intercalary and terminal conidiogenous cells. 6 Conidia. 7 Conidiophore from holotype showing percurrent extensions (arrowheads). 8 1-3septate conidia from holotype. 9-13 Specimen from culture (R. Kirschner 4019). 9 Conidiophores associated with rhizoidal structures at the base. 10 Conidiophore head. 11 Branches detached from conidiophore head. 12 Non-penicillate conidiophores. 13 Conidia.

- Scale bars $=10 \mu \mathrm{m}$, except $9,12=25 \mu \mathrm{m}$ 

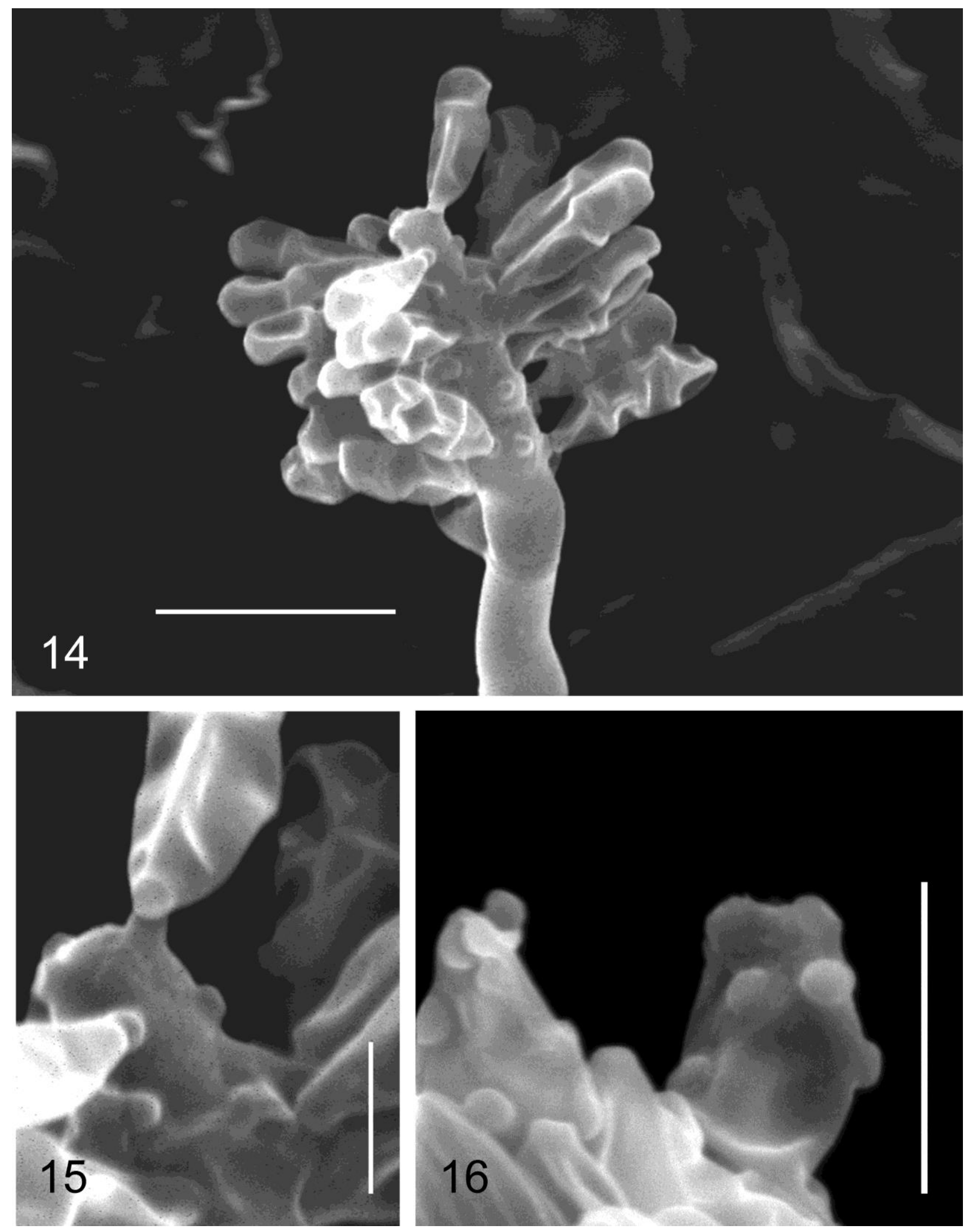

Figs 14-16 - SEM photographs of conidiogenous cells and conidiogenous loci from macronematous conidiophores of Thysanorea papuana (14, 15 from holotype, 16 from R. Kirschner \& C.-J. Chen 1356). - Scale bars: $14=10 \mu \mathrm{m}, 15=2.5 \mu \mathrm{m}, 16=5 \mu \mathrm{m}$.

prolonged cultivation, but show up to 4 levels of branching (up to 3 levels in the specimen from India, Pratibha \& Prabhugaonkar 2015) so that more complex branching appears to be an artifact of a degenerated culture. 
In the material from field collections from Taiwan, the conidiophore heads and branches break off easily from the stipe and seem to be replaced by regeneration after percurrent extension of the stipe apex (Figs 1, 4, 5). The same characteristic was also found in the holotype of Th. papuana (Fig. 7). This phenomenon was described as "axial proliferation of conidiogenous cells" as particular feature of $R$. lignicola and illustrated in Tsui et al. (2001, Fig. 10). This feature was also clearly shown for the specimen from India (Pratibha \& Prabhugaonkar 2015, Fig. 2). The type of $A$. lignicola was not available in HAC. A photograph of a conidiophore of A. lignicola in Mercado et al. (1996, Fig. 2) shows an abrupt change from the dark brown stipe to a pale head also indicating a break off of the stipe apex and percurrent extension by paler cells. The constrictions of septa and percurrent proliferation at the distal part of the conidiophores indicating a repeated break-off of the conidiogenous head or parts of it with subsequent regeneration appear to be different from other species retained in Periconiella. This easy break off and regeneration of the conidiogenous head by percurrent proliferation of the stipe apex seems to be a good morphological marker not only on the species level (Tsui et al. 2001), but also on the genus level. This kind of regeneration was not found for the conidiophores in culture by Arzanlou et al. (2007) nor in our study, probably due to the undisturbed growth in culture.

\section{Acknowledgements}

K.-L. Chen and C.-T. Lin (National Central University, Taiwan) are thanked for technical help with the molecular analysis and electron microscopy, respectively. The curators/directors of CBS-H, IFRD, and TNM are thanked for arranging loans of specimens. The curator of HAC is also thanked for checking the status of the type of A. lignicola. C.-J. Chen (Southern Taiwan University of Science and Technology, Tainan County) is thanked for arranging the collection trip in southern Taiwan. Another field trip was supported by National Central University. This study was supported by the Ministry of Science and Technology (formerly National Science Council) of Taiwan (NSC102-2621-B-008-001-MY3).

\section{References}

Aptroot A, van Iperen A. 1998 - New ascomycetes and ascomycete record from Papua New Guinea. Nova Hedwigia 67, 481-497.

Arzanlou M, Groenewald JZ, Gams W, Braun U, Shin HD, Crous PW. 2007 - Phylogenetic and morphotaxonomic revision of Ramichloridium and allied genera. Studies in Mycology 58, 57-93. DOI 10.3114/sim.2007.58.03.

Blaalid R, Kumar S, Nilsson RH, Abarenkov K, Kirk PM, Kauserud H. 2013 - ITS1 versus ITS2 as DNA metabarcodes for fungi. Molecular Ecology Resources 13, 218-224. DOI 10.1111/1755-0998.12065.

Gams W. 2002 - Ex situ conservation of microbial diversity. In: Sivasithamparam K, Dixon KW \& Barrett RL (eds) - Microorganisms in plant conservation and biodiversity. pp. 269-283. Kluwer Academic Publishers: Dordrecht.

Hashimoto A, Matsumura M, Hirayama K, Yonezawa H, Tanaka K. 2016 - Taxonomy and phylogeny of Cryptocoryneum (Pleosporales, Dothideomycetes). Mycological Progress 15 : 45, 1-12. DOI 10.1007/s11557-016-1186-8.

Heidarian Z, Arzanlou M, Babaei-Ahari, Ahmadpour A. 2016 - Phenotypic and molecular characterization of Exserohilum species from Iran. Nova Hedwigia 103, 327-338.

Jayasiri SC \& 55 coauthors 2015 - The Faces of Fungi database: fungal names linked with morphology, phylogeny and human impacts. Fungal Diversity 74(1), 3-18. DOI 10.1007/s13225-015-0351-8.

Kirschner R. 2016 - Alternaria bryophylli comb. nov. associated with leaf scab of Kalanchoe pinnata (Crassulaceae). Tropical Plant Pathology 41, 9-14.

Kirschner R, Chen C-J. 2010 - Periconiella species (anamorphic Mycosphaerellaceae) from Taiwan. Fungal Diversity 44, 135-148. DOI 10.1007/s13225-010-0054-0. 
Kirschner R, Piepenbring M. 2008 - Two new hyphomycetes parasitic on leaves of Maianthemum species in Panama. Mycological Progress 7, 21-29.

Kirschner R, Cáceres O, Piepenbring M. 2014 - New records of foliicolous hyphomycetes (anamorphic Dothideomycetes) from tropical lowland in Chiriquí, Panamá. Puénte Biológico 6, 1-17.

Kodsueb R, Lumyong S, McKenzie EHC, Bahkali AH, Hyde KD. 2016 - Relationships between terrestrial and freshwater lignicolous fungi. Fungal Ecology 19, 155-168.

Liu XY, Udayanga D, Luo ZL, Chen LJ, Zhou DQ, Su HY, Hyde KD. 2015 - Backbone tree for Chaetothyriales with four new species of Minimelanolocus from aquatic habitats. Fungal Biology 119(11), 1046-1062. DOI 10.1016/j.funbio.2015.08.005.

Ma J, Xia J-W, Zhang X-G, Castañeda-Ruiz RF. 2016a - Two new species of Solicorynespora from Jinggangshan Mountain, China. Nova Hedwigia 103, 117-124.

Ma J, Zhang K, Zhang X-G, Castañeda-Ruiz RF. 2016b - Three new species of Spadicoides from Lushan Mountain, China. Mycological Progress 15, 43, 2-8.

Mena-Portales J, Hernández-Restrepo M, Guarro J, Minter DW, Gené J. 2016 - New species of Penzigomyces, Sporidesmium and Stanjehughesia from plant debris in Spain. Nova Hedwigia 103, 359-371.

Mercado Sierra A, Figueras MJ, Mena Portales J. 1996 - A new species of Alisidiopsis from Mexico. Mycotaxon 60, 443-448.

Moro LB, Delgado G, Schoenlein-Crusius IH. 2015 - Polylobatispora setulosa, a new freshwater hyphomycete from Ilhabela, Sao Paulo state, Brazil. Mycosphere 6(1), 13-18. DOI 10.5943/mycosphere/6/1/3.

Pratibha J, Prabhugaonkar A. 2015 - New record of Thysanorea papuana from India. Mycosphere 6(4), 480-485. DOI 10.5943/mycosphere/6/4/9

Pratibha J, Bhat DJ, Prabhugaonkar A. 2016 - Molecular phylogeny of Speiropsis pedatospora. Mycosphere 7(5), 679-686. DOI 10.5943/mycosphere/7/5/12.

Silva SS, Castañeda-Ruiz RF, Gusmão LFP. 2016 - New species and records of Dictyosporium on Araucaria angustifolia (Brazilian pine) from Brazil. Nova Hedwigia 102, 523-530.

Tsui CKM, Goh TK, Hyde KD, Hodgkiss JI. 2001 - New records or species of Dictyochaeta, Endophragmiella and Ramichloridium from submerged wood in Hong Kong freshwater streams. Cryptogamie Mycologie 22(2), 139-145.

Xia J-W, Ma Y-R, Gao J-M, Zhang X-G, Li Z. 2016 - Two new species of Endophragmiella from southern China. Nova Hedwigia 103, 349-357.

Yeh YH, Kirschner R. 2014 - Sarocladium spinificis, a new endophytic species from the coastal grass Spinifex littoreus in Taiwan. Botanical Studies 55, 25, 1-6. DOI 10.1186/1999-3110$55-25$. 